\title{
National Courts and State Aid: Learning to Ask Good Questions
}

National judges play an essential role in the enforcement and development of the EU State aid rules that are one of the pillars of the European internal market. Many judges are concerned by these rules. According to a recent study, the number of judges within the 28 EU Member States who could potentially deal with State aid is large; the study even tries to calculate the number of judges potentially involved in the application of the State aid rules: 16,192 judges at first instance, 5,058 judges at appeal level, and 1,258 judges at final level. ${ }^{1}$

Foundational Treaties conceived very simple rules permitting the European Commission to control national authorities granting advantages to undertakings in order to ensure that competition will not be distorted. Nevertheless these rules are more and more complex in view of the legislative development by the Council, the broad administrative practice by the European Commission and national authorities, and the impressive case law of the Court of Justice. All these components are not easy to understand and to assemble by neither by specialised lawyers nor by national judges.

Needless to say, national judges are the key stone to ensure the effective control of State aid by the European Commission. In fact, case law developed by the Court of Justice is originated to a large extent by requests for preliminary rulings sent by national judges. The lack of prior notification to the Commission means that the aid is illegal and the recovery of an illegal aid is the logical consequence of a finding that is illegal. The unlawfulness and the recovery of an illegal aid have practical consequences as the Court of Justice has emphasised that 'it is for the national courts to draw the necessary consequences with regard to both the validity of the acts giving effect to the aid and the recovery of financial support granted'. ${ }^{2}$ Unlawfulness and recovery become crucial for understanding the State aid system and for ensuring its credibility.

Consequently, from a judicial point of view some relevant concepts regarding the enforcement of State aid are of great interest: to distinguish substantive and procedural issues; to analyse the interplay between EU and national levels; to develop criteria on the unlawfulness and incompatibility; to compare the different ways to reach the Court of Justice (actions of infringement or annulment and preliminary referrals); or even to construe basic principles as loyal cooperation and good faith between European (Commission and Court of Justice) and national authorities (governments and judges). As judge Vilaça has accurately said: 'National courts will therefore need guidance from the Commission and enlightenment from the Court. ${ }^{3}$

The Spanish Judicial School has been aware on judges' training needs regarding European competition law. In the last years, I was in charge of organising four training activities dedicated to judges from all the Member States in cooperation with the European Judicial Training Network (EJTN) and funded by the European Commission's Directorate- General of Competition: Seminar on Private and Public Enforcement of Competition (2012), Course on Enforcing European Competition Rules by National Judges (2013), Seminar on Fines and crimes before

DOI: $10.21552 /$ estal/2017/3/3

1 J Coughlan et alii, Study on judges' training needs in the field of European competition law, Final Report, European Commission, EU Publications Office, Luxembourg, 2016, 4.

2 Case C-71/04, Xunta de Galicia, EU:C:2005:493, 49.

3 JL da Cruz Vilaça, EU Law and Integration. Twenty Years of Judicial Application of EU Law, Hart, Oxford, 2014, 220. 
judges in the European competition law (2014), and Seminar on EU State Aid Rules and National Judges: Substantive and Procedural Issues (2017).

All these seminars were conceived in order to put together national judges and to share with European judges, lawyers and scholars, our opinions and experiences regarding competition law. This was an exercise of judicial training and networking.

Our last Seminar was held in Barcelona on 7-9 March 2017, and was focused on national judges and State aid. The main goals of this Seminar were, firstly, to improve the national judges training on EU rules on State aid regarding substantive (notion of aid) and procedural (unlawful aid) questions, in order to understand the implications between European and national level; and the relations between public authorities, recipients of the grants and competitors. Secondly, this Seminar was dedicated to discuss, analyse and share information regarding practical problems arisen from European State aid rules: notably in some areas as taxes, subsidies, public services (Services of General Economic Interest), etc. And, finally, the Spanish Judicial School sought to enhance requests for preliminary rulings to the Court of Justice and to promote the cooperation of the national judges with the European Commission and the National Competition Authorities regarding particular affairs (amicus curiae).

This Seminar was attended by 50 sitting judges from 12 Member States. In my view, it is compulsory to bridge the gap between theoretical analysis and pragmatic solutions concerning cases before national courts in order to fulfil uniform judicial implementation of State aid schemes all over the EU. Therefore, the speakers were mainly European (JL da Cruz Vilaça) and national Judges (HSJ Albers, A Garbe, M Pedraz, A Scott, S Soldevila and D Ordóñez); experienced lawyers before the Court of Justice (JL Buendía, A Creus, L Flynn - European Commission -, J Goyder and M Sampol - Spanish Government - ); and excellent scholars (E Szyszczak, D Jouve, A Metzelaar, S Moreno and G Riesgo).

Some of the papers produced by the Seminar are edited and presented at this issue. On behalf of the Spanish Judicial School I would like to thank the generosity and commitment of JL Buendía Sierra for the edition and our trainers in carrying out this task. Editing our papers, conceived initially for training purposes, could multiply their effects and, probably, could contribute to overcome 'divergent paths' between judges and scholars and doing so the gap between the academy and the judiciary should narrow 'because judges are practical rather than theoretical - doers rather than dreamers. ${ }^{4}$

In sum, we, national judges, need to be trained on European State aid schemes due to the fact that we are an essential instrument of enforcement of this policy. Nevertheless, this regime is notably dense and complex, requiring clarification. We may go to the European Commission or even we must bring our interpretive doubts to the Court of Justice. Thus, it seems to me that good answers involve asking good questions.

David Ordóñez-Solís* Guest editor

\footnotetext{
R A Posner, Divergent Paths. The Academy and the Judiciary, Harvard University Press, Cambridge, Massachusetts, 2016, 384.

Dr David Ordóñez-Solís is a Spanish senior judge and belongs to the Spanish Judicial Network on EU Law.
} 